\title{
НОРМАТИВНО-ПРАВОВЕ ВИЗНАЧЕННЯ ДИПЛОМАТИЧНОГО ІМУНІТЕТУ В КРИМННАЛЬНОМУ ПРОЦЕСУАЛЬНОМУ ЗАКОНОДАВСТВІ УКРАЇНИ
}

\author{
ГАНЕНКО Ігор Сергійович - здобувач Донецького юридичного інституту \\ МВС України
}

DOI:10.32782/NP.2019.4.15

УДК: 341.735:343.123.7

У статті розглянуто актуальні питання нормативно-правового визначення дипломатичного імунітету в кримінальному процесі Украӥни, враховуючи міжнародні правові акти, а також нормативно-правову основу внутрішнъого законодавства нашої держави. Розглянуто ключові підходи до визначення сутності дипломатичного імунітету, зосереджено увагу на найбільш прийнятних правових умовах реалізачї дипломатичного імунітету в національному кримінальному прочесуальному законодавстві України. Проаналізовано змістовне відображення ключових термінологічних визначень, положень дипломатичного імунітету в міжнародно-правових актах та запропоновано авторсъкий підхід до реалізациї дипломатичного імунітету у вітиизняному кримінальному прочесі.

Ключові слова: дипломатичний імунітет, міжнародно-правові стандарти, міждержавні угоди дипломатичного характеру, підходи до сприйняття сутності дипломатичного імунітету, нормативно-правове визначення дипломатичного імунітету в кримінальному процесі, особливості кримінального провадження щодо осіб наділених дипломатичним імунітетом.

\section{Постановка проблеми}

Нормативно-правове визначення дипломатичного імунітету є одним з актуальних питань реалізації інституту імунітету в кримінальному процесі України. Важливість цього різновиду імунітету важко переоцінити, оскільки формування належних міждер- жавних відносин є одним з провідних критеріїв функціонування зовнішньої політики держави. Враховуючи цей аспект сучасної правової дійсності, одним з ключових завдань законодавця $є$ належне та коректне нормативне відображення й врегулювання сфери реалізації дипломатичного імунітету в національній правовій системі.

\section{Актуальність теми дослідження}

Сучасна національна система кримінальної юстиції перебуває в стадії іiї реформування на відповідність європейським та світовим стандартам у забезпеченні прав та свобод людини й громадянина. Цей довготривалий та фундаментальний процес передбачає внесення суттєвих змін до чинних нормативних актів, що регулюють функціонування сфери вітчизняного кримінального правосуддя. Беззаперечно, перш за все це стосується кримінального процесуального кодексу України. Однак на даний час, попри вже наявні суттєві зміни в чинному кримінальному процесуальному законодавстві, залишаються не в повній мірі врегульовані питання щодо належного врегулювання в кримінальному процесі процесуального статусу осіб, які наділені дипломатичним імунітетом. Вказане зумовило вибір теми дослідження.

\section{Стан дослідження}

Питання, пов'язані 3 особливостями нормативно-правового визначення дипломатичного імунітету в кримінальному 


\section{Кримінальне право, кримінальний процес та криміналістика}

процесуальному законодавстві України, досліджувались такими науковцями, як: O.I. Бережний, Б.I Гуменюк, К.С. Ерьоміна, В.В. Мараховський, В.М. Репецький, К.К. Сандровський, В.В. Штучний та інші.

Метою статті є аналіз положень чинних нормативних актів, що регламентують реалізацію дипломатичного імунітету в кримінальному процесуальному законодавстві України, аналіз теоретичних положень щодо цього питання, висловлення та обгрунтування особистої точки зори щодо окремих питань забезпечення та реалізації дипломатичного імунітету у кримінальному процесі.

\section{Виклад основного матеріалу}

Імунітети, що врегульовані нормами міжнародного права, є прикладом інституцій 3 комплексним нормативним підходом до відображення їх сутності. Складність до вивчення їх сутності полягає в тому, що вони нормативно врегульовані системою нормативних актів, які включають як нормативні акти національного законодавства, так і міжнародного. Дипломатичні імунітети та привілеї надзвичайно чутлива категорія повсякденної дипломатичної практики. Вміле користування ними значно полегшує дипломатам виконання своїх професійних завдань і навпаки нехтування чи зловживання імунітетами може завдати значної шкоди як окремому дипломатові, так і акредитуючій державі [1].

Враховуючи наведене, стає зрозумілим, що будь-які кроки в напрямі оптимізації нормативного врегулювання сфери імунітетів дипломатичних представництв, а саме перш за все голови представництва, а також членів дипломатичного, адміністративнотехнічного та обслуговуючого персоналу дипломатичного представництва, мають бути максимально виваженими, оскільки стосуватимуться не лише сфери внутрішньодержавних інтересів, а й сфери міжнародних відносин між державами. Необачні та безрозсудні дії щодо внутрішньодержавного врегулювання сфери цих відносин як наслідок, може призводити до непорозумінь та дипломатичних скандалів, що неодмінно погіршуватиме відносини між державами.

Досліджуючи питання визначення імунітету дипломатичних представництв, $\lambda$. Федоров зазначав, що незалежність посла, посланника (і будь-якого дипломата) випливає із суверенітету і незалежності держави, яку представляє даний дипломат. Дозволяючи іноземному дипломату перебування на території власної держави, уряд тим самим бере на себе забезпечення недоторканності окремого дипломата i дипломатичного представництва в цілому [2, с. 95]. Схожої позиції дотримується І.П. Корякін, який наголошуе на тому, що в розрізі функціонування дипломатичного імунітету, стороною, що вирішує питання про користування даним привілеєм, є інша держава, яку по суті й представляє дипломат, а не державні органи як у випадку з наданням імунітету депутатам. 3 точки зору логіки, дані суб'єкти (іноземна держава та іï представник) справедливо ототожнюються, що відокремлює дипломатичний імунітет з групи переваг, які окреслюються як «Особливий порядок» та змушує нас вважати їх імунітетами [3, с. 34].

Аналізуючи наведені точки зору, необхідно зазначити, що, на наше переконання імунітет дипломата не може випливати з суверенітету держави, яку представляє ця особа, як зазначають згадані науковці. Вважаємо, що у такої позиції щодо сутності дипломатичного імунітету є певні недоліки. Так, наведена позиція будується не лише на звичаєвих нормативних перевагах, що мають міжнародно-правові акти над нормами внутрішнього законодавства. Згадані науковці у своїх переконаннях пропонують створення певного роду правової експансії правової системи іноземної держави до аналогічної системи держави, що акредитує дипломата. Запропонований погляд на сутність дипломатичного імунітету фактично означає нормативне його врегулювання виключно нормами держав, що акредитують дипломата та існування останнього виключно в правовому полі «своєї» держави під час реалізації особистих повноважень на території країни перебування дипломата.

На наш погляд, перш за все таке сприйняття сутності імунітету дипломатичного представника суперечуватиме змісту Віден- 
ської конвенції про дипломатичні зносини 1961 року (далі - Конвенція), оскільки саме цей документ вважається фундаментальним актом, що регулює дипломатичні зносини між державами. Цей нормативний акт є надбанням міжнародно-правової дійсності, затверджувався сторонами Конвенції, відзначаючи, що народи всіх країн 3 давніх часів визнають статус дипломатичних агентів, беручи до уваги цілі і принципи Статуту Організації Об'єднаних Націй щодо суверенної рівності держав, підтримання міжнародного миру та безпеки і сприяння розвитку дружніх відносин між державами. Ключовим аспектом, як на нашу думку, є саме дотримання суверенної рівності держав, що укладають подібного роду дипломатичні зносини. У свою чергу, запропонована позиція науковців нівелює саме критерій суверенної рівності таких держав. Навіть за умов обопільного обміну агреманами щодо акредитації дипломатичних представництв, функціонування дипломатичних представництв за запропонованих критеріїв створюватиме певну атмосферу зневаги до національного законодавства з боку держави, що акредитувала дипломатичну місію. Негативні приклади подібної зневаги національним законодавством ми наведемо нижче. Отже, на наше переконання, сутність ключового критерію дипломатичного імунітету полягає в тому, що держава, яка приймає дипломата, забезпечує йому виключне положення на своїй території та повністю або частково виводитиме його з під дії внутрішніх, нормативних, державних регуляторів. Це відбувається у виняткових випадках та щодо вельми обмеженого кола осіб, враховуючи мету та значення цієї «міжнародної місії».

Провідна роль держави, що приймає на своїй території дипломатичну місію та забезпечує їй належні умови для функціонування, покладено в основу нігілістичної концепції походження міжнародного імунітету. У цьому аспекті слід зазначити, що науковці, які досліджують питання визначення міжнародного імунітету, оперують трьома теоріями співвідношення міжнародного та національного права. Першою є дуалістична теорія. Ця доктрина виходить 3 того, що міжнародне та внутрішньодержавне право
- це два різних правопорядки, які не перетинаються один з одним, не можуть бути поставлені один над іншим, а діють абсолютно відокремлено та самостійно. Прибічники цієї доктрини вважають, що норми міждержавного права не мають жодного впливу всередині держави, а норми внутрішньодержавного права - у міжнародних відносинах.

Наступною 6 моністична доктрина, яка базується на тому, що міжнародне та національне право - це частини єдиного правопорядку, однак міжнародне право має більш широкий спектр дії, займає більш високе місце в загальній системі права, ніж національне, тому має пріоритет над останнім. На думку прибічників цієї доктрини, норми міжнародного права є частиною національного права всіх держав.

Третьою теорією є нігілістична доктрина, яка виходить з того, що міжнародне право, яке знайшло відображення в національному 6 ніщо інше як «зовнішнє державне право» окремих держав. Представники цієї теорії вважають, що для кожної держави як під час внутрішніх відносин, так і на міжнародній арені можуть мати значення лише ті юридичні норми, які основані на юридичних актах держави, а поза цим міжнародні норми, які містять лише політичні та етичні побажання. Між тим дуалістична й нігілістична концепції сходяться в тому, що норми, які регулюють дипломатичний та інші різновиди імунітету, основані на міждержавній взаємодії, вимагають того, щоб вони регулювались нормами національного права. При цьому більшість країн дотримується нігілістичної теорії [4, с. 141].

Досліджуючи зазначені теорії походження дипломатичного імунітету, С.В. Аукошкіна зазначає, що і в міжнародному праві немає єдиного законодавця, та у зв'язку з цим цілком логічні питання щодо визначення сутності дипломатичного імунітету мають вирішуватись, виходячи 3 власного національного менталітету та волі держави, а не 3 приписів, хоча й таких, які вважаються міжнародними, але породжені правом інших держав. Іншими словами, на думку автора, держава повинна мати власну національну позицію за тим чи іншим питанням, у тому числі й питання щодо визначення імуніте- 


\section{Кримінальне право, кримінальний процес та криміналістика}

ту в міжнародному праві [4, с. 141]. У цьому аспекті С.В. Аукошкіна підтримує А. Цорна, який наголошував, що посольське право є частиною державного права, обов'язкового для окремих держав, його не існує [5, с. 177].

Частково погоджуючись 3 вказаною позицією науковців, вважаємо за потрібне висловити особисту точку зору щодо цього. Як ми вже вище зазначали, держава, що приймає дипломатичну місію має забезпечити iii належне функціонування на своїй території, керуючись лише нормами міжнародного права. Провідну роль при цьому мають відігравати норми національного законодавства, оскільки міжнародно-правові акти комплексно не відображають всієї специфіки дипломатичних відносин, що можуть виникати в кожній окремій державі, що приймає дипломатичні місії, слід наголосити, що міжнародно-правовими актами й не ставиться за мету регулювання правовідносин подібного характеру. Зазначеними нормативними актами лише визначаються ключові стандарти такого різновиду міжнародних зносин, які перш за все стосуються безпеки дипломатичної місії та питань належного іï функціонування. Окремі критерії забезпечення виконання вказаних ключових міжнародно-правових напрямів, на наше переконання, мають визначатись нормами національного законодавства. При цьому, ми не погоджуємось $з$ поглядами вищевказаних науковців щодо необов'язковості міжнародно-правових приписів для держави, що приймає дипломатичну місію, з причини того, що начебто вказані міжнародні акти є приписами, що «породжені» правом іншої держави.

По-перше, ці міжнародно-правові акти не $є$ похідними від законодавця якоїсь конкретної держави, а актом, що прийнятий колегіально за участі низки держав. Так, наприклад, вищезгадана Віденська конвенція про дипломатичні зносини була прийнята на міжнародній конференції у Відні, яка проходила в період з 2 березня по 14 квітня 1961 року. У конференції взяла участь 81 держава. Станом на 2014 рік у ній беруть участь уже 190 держав. Отже, ця Конвенція відображає волю всіх вказаних держав, а не є похідною від національного законодавства конкретної держави.

По-друге, саме міжнародно-правовим актам надається пріоритет перед нормами національного законодавства. Так, зокрема, відповідно до ст. 9 Конституції чинні міжнародні договори, згода на обов'язковість яких надана Верховною Радою України, є частиною національного законодавства України. Також згідно зі ст. Х Декларації про державний суверенітет України, нашою державою визнається пріоритет загальновизнаних норм міжнародного права перед нормами внутрішньодержавного права. Додатково необхідно навести одне з положень ЗУ «Про міжнародні договори України». Відповідно до ст. 19 закону, чинні міжнародні договори України, згода на обов' язковість яких надана Верховною Радою України, є частиною національного законодавства і застосовуються у порядку, передбаченому для норм національного законодавства. Якщо міжнародним договором України, який набрав чинності в установленому порядку, встановлено інші правила, ніж ті, що передбачені у відповідному акті законодавства України, то застосовуються правила міжнародного договору.

Отже, наведене свідчить про наявну важливість норм міжнародного права для всієї сфери національного законодавства. Однак попри значимість та важливість міжнародно-правових актів для національної правової системи, вітчизняний законодавець має вдосконалювати нормативно-правові акти задля не лише приведення їх у відповідність до норм міжнародного права, а й $з$ метою вирішення ситуацій, які фізично не можуть регулюватись нормами міжнародного права, враховуючи специфіку внутрішньодержавної сфери правовідносин.

Як ми зазначали раніше використання лише норм міжнародного права під час регулювання сфери внутрішньодержавних правовідносин, у які вступають представники дипломатичних місій та особи конкретної держави та/або державні інституції, призводитиме до певної зневаги нормами національного права та породжуватиме негативні наслідки. Стосовно цього Д. Кєллі зауважує, що згідно з Віденською конвенцією про дипломатичні відносини (1961), дипло- 
мати звільнені від судового переслідування у країні перебування. Автор підкреслює, що за таких умов особа може порушувати закон - i ніхто їі не зупинить. Вона може забути про штрафи за неправильне паркування, не перейматися податками. Навіть за вбивство їй нічого не буде. Теоретично усе це можливо, якщо ви - посол, підсумовує автор [6]. Також у своїй статті Д. Кєллі наводить окремі практичні приклади реалізації повноважень осіб, що користуються дипломатичним імунітетом на практиці. Ми, зі свого боку, вважаємо за потрібне навести ці приклади у своїй роботі, оскільки вони яскраво демонструють прикладні аспекти зневаги нормами національного законодавства під час регулювання правовідносин, пов'язаних 3 реалізацією дипломатичного імунітету на території держави, яка приймає дипломатичну місію.

Отже, відповідно до змісту Конвенції, дипломати звільнені від судового переслідування у країні перебування. Ця система неодноразово викликала суперечки - наприклад, коли у 1984 р. від кулі, що вилетіла із посольства Лівії у Лондоні, загинула поліцейський Івонн Флетчер (Yvonne Joyce Fletcher). Нині ж про це знову заговорили у зв'язку з неординарною справою, що розглядалася у кількох лондонських судах. Цей трагічний випадок набув досить широкого розголосу в британському суспільстві. Втім, це вже не перший випадок, коли в суспільстві піднімають серйозні сумніви щодо цього інституту, який лише у Британії охоплює близько 25 тисяч людей - як посадовців, так і членів їхніх сімей.

У 2010 році тодішній міністр закордонних справ Вільям Гейг (William Jefferson Hague) оприлюднив дані про 18 злочинів на території Британії, включно із сексуальним нападом, торгівлею людьми, погрозами про вбивство та керуванням автомобілем у нетверезому стані, у яких протягом року звинуватили дипломатів. У грудні цього ж року газета Financial Times повідомила, що працівники посольств не сплатили зборів за користування завантаженими дорогами на 95 млн фунтів (близько 136 млн доларів); вони стверджують, що це податок, а не плата за послугу, а відтак Віденська конвенція звільняе їх від оплати цих зборів.

У лютому 2016 року одним із судів постановлено, що завдяки своєму дипломатичному статусу шейх Хамад бін Джасім бін Джабер Аль-Тані - один із найбагатших людей світу та колишній прем'єр Катару - не підлягає судовому переслідуванню у Британії через звинувачення у несправедливому ув'язненні чоловіка із подвійним британсько-катарським громадянством. Шейх Хамад та уряд Катару заперечили будь-які правопорушення. Юристи мільярдера заявили, що з чоловіком, про якого йдеться, обійшлися «згідно 3 катарським та міжнародним законодавством».

Також автором наводяться додаткові приклади згаданої проблематики щодо виникнення конфліктних ситуацій під час реалізації дипломатичних імунітетів. Так, у 2013 році в Нью-Йорку заарештували заступницю генерального консула Індії Девіані Хобгараде (Devyani Khobragade). Ïї звинуватили у наданні неправдивої інформації для отримання візи. Посада не наділяла затриману дипломатичним імунітетом, але уряд Індії перевів їі на іншу посаду в ООН, яка вже передбачала імунітет. Пані Хобгараде заперечила свою провину.

Катарський шейх Халід Хамад Аль-Тані раптово залишив СІІА, коли в інтернеті з'явився відеозапис, на якому його «феррарі» бере участь у спринтерських перегонах у Беверлі-Гіллз. Чи був у нього дипломатичний імунітет - питання суперечливе; крім того, поліція так і не встановила, хто був за кермом.

У Нідерландах поліція затримала російського дипломата Дмитра Бородіна і тримала його під охороною три години, попри дипломатичну недоторканість. За повідомленнями місцевої преси, поліцію викликали через звинувачення у жорстокості до дітей, а Бородін був у стані алкогольного сп'яніння. МЗС Росії та пан Бородін палко заперечували звинувачення.

У 1997 році уряд Грузії скасував дипломатичний імунітет свого дипломата Георгія Махарадзе, коли той спричинив у Вашингтоні аварію, в якій зіткнулися п'ять автомобілів і загинула дівчина-підліток [7].

Такі випадки призвели до закликів пе- 


\section{Кримінальне право, кримінальний процес та криміналістика}

реглянути всю систему. Джеффрі Робертсон (Jeffrey Robertson), королівський адвокат i фахівець із прав людини, вважає, що Віденська конвенція мала сенс у часи холодної війни, коли дипломатичному персоналу у ворожих країнах загрожували усілякі пастки, але зараз вичерпала себе. «По суті, вона ставить дипломатів над законом, - каже він. - Це порушує Велику хартію вольностей». «На мою думку, стверджує адвокат, у Віденську конвенцію треба внести поправки, які би обмежували імунітет дипломатів. Не думаю, що його слід поширювати на цивільні справи. Він має стосуватися лише кримінальних справ за певних обмежених обставин» [7].

Погоджуємо з позицією вказаного правника щодо нормативного врегулювання певного обмеження користування особою дипломатичним імунітетом. Одним з шляхів вирішення цього питання полягає в тому, що від Імунітету юрисдикціїі дипломатичного агента може відмовитися акредитуюча держава. Це робиться без його згоди, і дипломат зобов'язаний підкоритися прийнятому рішенню. Як приклад варто навести один з випадків згаданих нами вище. Отже, така практика мала місце після трагічного випадку у Вашингтоні наприкінці 1996 р., коли в результаті автомобільної аварії, 3 вини грузинського дипломата, загинула 16-річна громадянка СШІА. Дипломат, як було доведено, перебував за кермом свого авто у стані алкогольного сп'яніння, і на вимогу Держдепартаменту СШІА МЗС Грузії змушене було позбавити свого дипломата імунітету. Йому довелося нести кримінальну відповідальність за американськими законами [1].

Враховуючи викладене необхідно зазначити, що міжнародна практика має прецеденти щодо застосування правових важелів впливу на особу, що користується дипломатичним імунітетом, враховуючи навіть вироблення механізму притягнення до кримінальної відповідальності. Отже за загальним правилом, особа, яка користується дипломатичним імунітетом, у випадку вчинення нею злочинного діяння може бути визнано державою його перебування, керуючись ст. 9 Конвенції як persona non grata.
3 відповідними наслідками для такої особи, які визначені у вказаній статті міжнародноправового акту. Разом 3 тим, сторона, що приймає, може клопотатися перед урядом держави, що акредитує, про відмову в імунітеті дипломату, що вчинив злочин. При його одержанні така відмова повинна бути ясно і точно виражена [8, с. 37]. На наше переконання за умов, якщо акредитуюча держава позбавить окрему особу, що вчинила злочин на території країни перебування, дипломатичного імунітету, то така особа має притягуватись до кримінальної відповідальності на підставі чинних норм КПК. Врештірешт вищенаведений приклад 3 трагічним випадком, що стався у США в 1996 р., доводить про актуальність та дієвість існування подібного механізму притягнення особи, яка користується дипломатичним імунітетом до кримінальної відповідальності.

Ми зі свого вважаємо, що використання нашою державою окресленого правового механізму притягнення осіб, що користуються дипломатичним імунітетом до кримінальної відповідальності, робитиме вітчизняну правову систему більш досконалою та визначені правовідносини у сфері реалізації дипломатичного імунітету в межах національного законодавства матимуть завершений вигляд. Таким чином, оптимізація внутрішньодержавного законодавства, враховуючи сферу кримінальних процесуальних відносин, має відбуватись 3 урахуванням окремої специфіки реалізації в правовому полі нашої держави правовідносин, що поєднують у собі як норми міжнародного права, так і національного. У даному випадку мова йде про специфіку реалізації дипломатичного імунітету окремих осіб.

Запровадження правового механізму щодо реакції держави на незаконні дії осіб, що користуються дипломатичним імунітетом має бути максимально виваженим 3 тим, щоб не суперечити вимогам Конвенції, а також ретельно зваженим щодо можливих міждержавних наслідків, які не завжди позитивним чином вливатимуть на відносини між Україною та іншими державами. Втім, такий крок має бути зроблений нашою державою, оскільки він ознаменуватиме сучасну позицію держави до захисту власних інтере- 
сів від свавільних та незаконних дій осіб, що користуються дипломатичним імунітетом.

Запровадження вказаного правового механізму стикатиметься з певними перешкодами не лише правого змісту, а й 3 поглядами осіб, що досліджують вказану проблематику. Однією з таких перешкод, на нашу думку, є коректна правова регламентація початку кримінального провадження щодо вчиненого кримінального правопорушення особою, яка користується дипломатичним імунітетом. Так, по-перше, відповідно до ст. 31 Конвенції, дипломатичний агент користується імунітетом від кримінальної юрисдикції держави перебування. По-друге, спираючись на це положення Конвенції, науковці висловлюють категоричні позиції щодо заборони будь-якого кримінального переслідування особи, що користується дипломатичним імунітетом. Так, В.М. Репецький стверджує, що імунітет від кримінальної юрисдикції на практиці означає повне вилучення цих осіб з-під дії судових і слідчих органів приймаючої держави. Проти них не може бути порушено кримінальну справу [9, с. 267]. O.I. Бережний 3 цього приводу також наголошує, що у випадку вчинення особою, що користується дипломатичним імунітетом кримінально караного діяння кримінальне провадження стосовно нього не розпочинається в силу даного імунітету. Далі автор зазначає, що така особа оголошується persona non grata і їй пропонується залишити територію держави перебування [8, c. 38].

Категоричність позицій науковців щодо заборони кримінального переслідування є в цілому зрозумілою, враховуючи категоричність міжнародно-правових приписів. Хоча 3 висловлюванням О.I. Бережного є незрозумілою наступна обставина. Яким чином державні органи країни перебування можуть визначити, що саме особа, яка користується дипломатичним імунітетом, вчинила певний злочин, за умов, що заборонено розпочинати кримінальне провадження та, відповідно, вчиняти будь-які слідчі (розшукові) дії та здійснювати процедуру доказування? Невже можна вважати виваженим кроком 3 боку державних органів щодо клопотання до уряду держави, що акредитує, про відмо- ву в імунітеті дипломату, що вчинив злочин або оголошення цю особу як persona non grata за умов фактичної відсутності доказів, у кримінальному процесуальному розумінні, вчинення такою особою кримінального правопорушення?

На наше переконання, як ми вже зазначали, будь-які висунуті звинувачення з боку державних органів країни перебування до особи, яка користується дипломатичним імунітетом, мають бути обгрунтованими, оскільки будь-які суперечності щодо цього можуть породжувати вельми серйозні наслідки на державному рівні. У зв'язку 3 чим, на наше переконання, неможливо остаточно стверджувати про факт вчинення конкретною особою, що користується дипломатичним імунітетом, злочинного діяння без проведення ретельного розгляду та аналізу щодо цього факту та всіх обставин пов'язаних $з$ ним. Тому вважаємо, що здійснити це неможливо без проведення кримінального провадження.

Як ми зазначали, раніше відповідно до ст. 31 Конвенції наділяе дипломатичного агента імунітетом від кримінальної юрисдикції держави перебування. Це положення міжнародно-правового акту потребує ретельного аналізу. Так, відповідно до тлумачного словника термін «юрисдикція» походить від латинського «jurisdictio» - тобто ведення судівництва, судовий розгляд або право проводити суд [10 с. 524]. Отже, буквальне тлумачення цього терміну дозволяє дійти висновку, що дипломатичний агент наділений дипломатичним імунітетом від судової стадії кримінального провадження за кримінальним правопорушенням, що, відповідно, не розповсюджується на стадію досудового розслідування.

\section{Висновки}

Підсумовуючи вищевикладене, слід зазначити, що, нормативно забезпечивши особі, що користується дипломатичним імунітетом, стан недоторканності на ключовій стадії кримінального провадження, а саме стадії судового розгляду, тобто тієї стадії під час якої таку особу можуть визнати винною у вчиненні злочину, залишається можливим провадження стадії досудового розслідуван- 


\section{Кримінальне право, кримінальний процес та криміналістика}

ня. Саме під час реалізації такої стадії існуватимуть законні, правові важелі щодо здійснення доказування у справі та аргументоване та обгрунтоване доведення провини у вчиненні злочину особою, що користується дипломатичним імунітетом. На наше переконання, лише після отримання належної доказової інформації щодо злочинної діяльності дипломатичного агента, компетентні державні органи матимуть можливість, без ризику виникнення негативних міжнародних наслідків, за умов безпідставного звинувачення дипломатичного агента, клопотатися перед урядом держави, що акредитує, про відмову в імунітеті дипломату, що вчинив злочин та/або оголошення таку особу persona non grata. Отже, на наше переконання, використання правового механізму збору доказів та доведення провини або, навпаки, доведення непричетності дипломатичного агента до вчиненого злочинного діяння, у вигляді стадії досудового розслідування, є необхідним кроком, який слугуватиме тим самим критерієм рівноваги, що забезпечуватиме баланс між дотриманням вимог міжнародно-правових актів та угод, що регламентують сферу реалізації дипломатичного імунітету та внутрішньодержавного інтересу й належного функціонування сфери кримінального судочинства держави.

\section{Мiтература}

1. Дипломатичні привілеї та імунітети [Електронний ресурс]. URL: http://kimo.

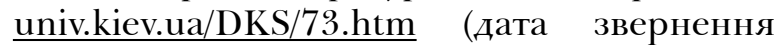
$01.12 .2019)$

2. Федоров ᄉ. Дипломат и консул. М. : Междунар. отношения, 1965. С. 95.

3. Корякин И.П. Иммунитет в уголовном судопроизводстве : дис. ... канд. юрид. наук : 12.00.09. К., 2002. 160 с.

4. Лукошкина С.В. Иммунитеты в российском уголовном процессе : дис. ... канд. юрид. наук : 12.00.09. И., 2005. 224 с.

5. Аевін Д.Б. Дипломатичний імунітет. М. : Видавництво Академії наук СРСР, 1949. $415 \mathrm{c}$.

6. Кєллі Д. Чи не пора скасувати дипломатичний імунітет? [Електронний ресурс].
URL: https://zib.com.ua/ua/123112-chi_ne= pora_skasuvati_diplomatichniy_imunitet.html (дата звернення 01.12.2019)

7. Кєллі Д. Чи повинні дипломати мати недоторканність? [Електронний реcypc]. URL: https://www.bbc.com/ukrainian/ politics/2016/04/160401 diplomatic immunity or (дата звернення 01.12.2019)

8. Бережний О.I. Особливості притягнення до кримінальної відповідальності окремих категорій осіб та доказування у таких кримінальних провадженнях. The Journal of Eastern European Law. Журнал східноєвропейського права. 2015. № 21. С. 38

9. Репецький В. М. Дипломатичне і консульське право: Підручник. 2-ге вид., перероб. і доп. К.: Знання, 2006. 372 с.

10. Мельничук О. С. Етимологічний словник української. Т. 6. К. : Наукова думка, $1985.573 \mathrm{c}$.

Legal and regulatory definition of diplomatic immunity in the criminal procedural legislation of Ukraine

The article has examined the current power of the legal framework for diplomatic cooperation in the criminal process of Ukraine and the international legal framework, as well as the legal framework for the internal legislation of our country. The keys to understanding the day of the diplomatic immunity were considered, respect for finding the right legal minds for realizing the diplomatic immunity in the national criminal procedural legislation of Ukraine was extended. The analysis of the identification of the key terminological cards, the position of the diplomatic certificate in the international legal acts and the copyright of the reader to the implementation of the diplomatic certificate for the criminal process has been analyzed.

Key words: diplomatic immunity, international legal standards, diplomacy of the diplomatic nature, approach the current diplomatic immunity, legal diplomacy in criminal proceedings, and especially high degree of crime. 